\title{
Abdominal Compartment Syndrome - a Surgical Emergency
}

\author{
Bogdan Socea', Anca Andreea Nica², Alexandru Smarandaㄹ, Ovidiu Gabriel Bratu ${ }^{3}$, \\ Camelia Cristina Diaconu, Alexandru Constantin Carap ${ }^{7}$, Tiberiu Paul Neagu ${ }^{5}$, Cristinel Dumitru Badiu ${ }^{6}$, \\ Vlad Denis Constantin ${ }^{7}$
}

\begin{abstract}
Over the past six decades, abdominal compartment syndrome (ACS) remained a very controversial subject, both in surgical and non-surgical specialties. Doctors failed to understand why critically ill patients died in the ICU with distended abdomens without finding any cause or why postoperative patients with wound defects such as dehiscence died after suturing the wound again "very tightly". After the concept of intra-abdominal pressure (IAP) was established and methods for measuring it and diagnosing intra-abdominal hypertension (IAH) were available for clinicians to use it, it became clearer that ACS was a very serious and life threating pathology and the need for a correct treatment is essential. In this article we will try to make a literature review of the past decade and see when and how to diagnose correctly a patient with ACS and also how the diagnostic and treatments methods changed over the years.
\end{abstract}

Keywords: abdominal compartment syndrome, high intra-abdominal pressure

\section{Rezumat}

În ultimele șase decenii, sindromul compartimentului abdominal a rămas un subiect foarte controversat, atât în specialitățile chirurgicale, cât și în cele non-chirurgicale. Medicii nu înțelegeau de ce pacienții în stare critică decedau în ATI cu abdomenul destins, fără a găsi nicio cauză sau de ce pacienții cu eviscerații postoperatorii, decedau după resuturarea „foarte strânsă" a plăgii. După ce a fost stabilit conceptul de presiune intraabdominală și au fost disponibile metode pentru măsurarea și diagnosticarea hipertensiunii intra-abdominale pentru clinicieni, a devenit mai clar că sindromul de compartiment reprezintă o patologie foarte gravă, care amenință viața și că necesitatea unui tratament corect este esențială. În acest articol vom încerca să facem o revizuire a literaturii ultimului deceniu și să vedem când și cum diagnosticăm corect un pacient cu sindrom de compartiment și, de asemenea, modul în care metodele de diagnosticare și tratament s-au schimbat de-a lungul anilor.

Cuvinte cheie: sindrom de compartiment, presiune intra-abdominală crescută

\footnotetext{
1 Department of Surgery, "Sf. Pantelimon" Emergency Clinical Hospital, "Carol Davila" University of Medicine and Pharmacy, Bucharest, Romania

2 Department of Surgery, „Sf. Pantelimon" Emergency Clinical Hospital, Bucharest, Romania

${ }^{3}$ Department of Urology, „Dr. Carol Davila" Central Military Clinical Hospital, „Carol Davila" University of Medicine and Pharmacy, Bucharest, Romania

${ }^{4}$ Department of Internal Medicine, Emergency Clinical Hospital, "Carol Davila" University of Medicine and Pharmacy, Bucharest, Romania

${ }^{5}$ Department of Plastic Surgery and Reconstructive Microsurgery, Emergency Clinical Hospital, „Carol Davila" University of Medicine and Pharmacy, Bucharest, Romania

${ }^{6}$ Department of Surgery, "Bagdasar Arseni" Emergency Clinical Hospital, „Carol Davila" University of Medicine and Pharmacy, Bucharest, Romania
}

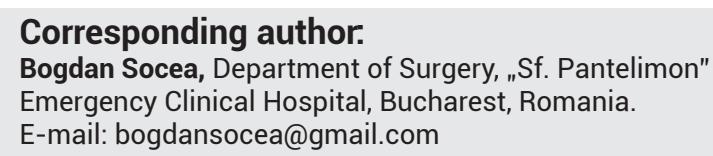




\section{INTRODUCTION}

Abdominal compartment syndrome is defined as hypoperfusion and ischemia of intra-abdominal viscera and structures caused by raised intra-abdominal pressure. It occurs most commonly following major trauma and complex surgical procedures, but can also occur in their absence ${ }^{1}$.

Compartment syndrome occurs whenever increasing pressure within a confined anatomic space undermines the normal cellular functions of the tissues contained within that space 2 . Most commonly, compartment syndrome involves the extremities; tissue edema below the fascial layer causes ischemia and eventual muscle necrosis.

The peritoneal cavity is another confined anatomic space. Although the notion is not new, trauma clinicians are becoming more aware that increased pressure within the abdomen impairs organ function ${ }^{3}$. This condition is known as intra-abdominal hypertension and can lead to the development of ACS, with potentially devastating consequences.

Some abnormalities that elevate the pressure within the peritoneal cavity can have as consequence abdominal compartment syndrome.

For a better understanding of this diagnosis, we must first define and understand the differences between intra-abdominal pressure and intra-abdominal hypertension. IAP is the steady-state pressure within the $a b-$ dominal cavity ${ }^{4}$. In healthy persons, IAP is 0 to $5 \mathrm{~mm}$ $\mathrm{Hg}^{3}$ and varies inversely with intra-thoracic pressure during normal breathing. Different factors, such as coughing, sneezing, and loud singing, can cause IAP to increase drastically for short periods of time and then return easily to baseline. IAP is also increased in persons who are morbidly obese, have chronic ascites, or are pregnant. In these chronic forms, the increase develops slowly and the body adjusts to the change. Patients with chronically increased IAP do not experience the systemic effects of IAH. The mean IAP in critically ill adults is approximately 5 to $7 \mathrm{~mm} \mathrm{Hg}^{5}$.

Intra-abdominal hypertension occurs when IAP is pathologically elevated and sustains a value of 12 $\mathrm{mmHg}$ or greater. Abdominal compartment syndrome happens when IAP is greater than $20 \mathrm{mmHg}$, associated with new organ dysfunction or failure.

Definitions of intra-abdominal hypertension (IAH) or abdominal compartment syndrome (ACS) stand or fall with the accuracy and reproducibility of the intraabdominal pressure (IAP) method used ${ }^{6}$. Not only the absolute cut-off, but also the use of mean, median or maximal IAP values will influence the prevalence and incidence of IAH and ACS. Various methods are used for direct and indirect measurements of IAP such as: bladder technique, through the stomach (the classic intermittent technique - the IAP can also be measured by means of a nasogastric or gastrostomy tube and this method can be used when the patient has no Foley catheter in place, or when accurate bladder pressures are not possible due to the absence of free movement of the bladder wall). In case of bladder trauma, peritoneal adhesions, pelvic hematomas or fractures, abdominal packing, or a neurogenic bladder, intra-bladder pressure may overestimate IAP, and the procedure used for the bladder can then be applied via the stomach ${ }^{7}$, uterine pressure, rectal pressure (used in urodynamic studies) and inferior vena cava pressure, but the golden standard remaining via a urinary bladder catheter ${ }^{8}$.

Prediction scores are also used in the diagnostic process, scores such as SOFA (sequential organ failure assessment), Modified Marshall and Apache II help clinicians follow a correct diagnostic route.

What method is the most efficient? When do we use the bladder/rectal/stomach or uterine pressure for diagnosing ACS?

Are prediction scores useful in diagnosing abdominal compartment syndrome? What treatment methods should we use depending of the pathology that caused ACS?

We should permanently have all these questions in mind.

\section{Primary and secondary abdominal compartment syndrome}

With the rising recognition of ACS as a significant contributor to the development of multiple organ failure in critically ill patients, and the multitude of conditions associated with ACS, it is useful to categorize ACS according to the underlying pathology. In trauma patients, primary ACS has been defined as a recognized complication of damage control laparotomy, and secondary ACS as a condition reported in patients without abdominal injury who require aggressive fluid resuscitation ${ }^{9,10}$. In recent literature, primary abdominal compartment syndrome was defined as surgical such as: trauma or abdominal aortic aneurysm rupture and secondary ACS defined as medical (toxic shock, massive fluid overload, capillary leak etc.).

Besides primary and secondary ACS, WSACS (World Society of the Abdominal Compartment Syndrome) 
recognizes a third category: recurrent ACS. Recurrent conditions are ones in which ACS redevelops after surgical or medical treatment of primary or secondary causes of ACS.

In primary ACS, patients often need decompression laparotomy, a surgical technique that doesn't require an experienced surgeon, but closing of the abdomen is always an issue. Abdominal closure in ACS vary from: temporary abdominal closure, towel clip closure, Bogota bag, mesh closure and vacuum assisted wound closure.

There are no studies to show which method is the most efficient, therefore the surgeon must choose one based on his personal experience with the technique.

Abdominal closure techniques are all temporary in ACS, after decompression laparotomy is performed and the abdomen is closed, patient is moved into ICU for fluid resuscitation and continuously monitoring IAP and avoiding IAH to reappear.

\section{Best measuring method for IAP}

The WSACS advocates the use of the modified Kron technique as the gold standard of IAP measurement ${ }^{11-13}$. The Kron method assesses the IAP via bladder pressure measurement using a maximum instillation of $25 \mathrm{ml}$ of sterile saline ${ }^{12}$. The measurement is taken:

1. With the transducer zeroed and positioned in line with the iliac crest and mid-axillar.

2. With the patient in a supine position.

3. At end-expiration.

4. With an instillation volume of no greater than $25 \mathrm{~mL}$ of saline (for bladder technique).

5. 30-60 seconds after instillation to allow for bladder detrusor muscle relaxation (for bladder technique) ${ }^{10-12,14,15-16}$.

There are isolated cases when IAP measurement via the direct bladder method is not feasible. These include patients with ruptured bladders, intra bladder hematoma, neurogenic bladder, recent bladder surgery and urogenital anomalies ${ }^{17-18}$.

\section{Interpreting the results}

The IAP is expressed in $\mathrm{mm} \mathrm{Hg}$ (for $\mathrm{cm} \mathrm{H}_{2} \mathrm{O}$, a conversion factor of 1.34 should be taken into account). Normal IAP is around 0 to $5 \mathrm{~mm} \mathrm{Hg}$. Sanchez found a mean IAP of $6.5 \mathrm{~mm} \mathrm{Hg}$ in a randomly selected sample of 77 hospitalized patients ${ }^{19}$. Pressures of $15 \mathrm{~mm}$ $\mathrm{Hg}$ may be normal after abdominal surgery; however pressures higher than $10-15 \mathrm{~mm} \mathrm{Hg}$ may indicate early IAH. Not necessarily the absolute value, but the trend of IAP over time together with the presence of organ dysfunction should alert the clinician to prevent ACS.

Since IAH and ACS cannot be diagnosed by physical examination alone and frequent IAP measurements are important to effectively resuscitating such patients, choosing and implementing an IAP measurement technique in the ICU is essential in improving patient morbidity and mortality. Of course, the optimal measurement technique is the one that is safe, rapid, accurate, and cost-effective. While regional variations and financial considerations may guide clinician choices of technique to an extent, the best technique is the one that you and nursing staff will use.

\section{SOFA/Modified Marshall and APACHE II}

Prediction scores are important in diagnostic approach but they don't make the diagnosis.

The modified Marshall scoring system has the merit of simplicity, universal applicability across international centers, and the ability to stratify disease severity easily and objectively ${ }^{20}$. The downside of Modified Marshall is that this score is used to evaluate organ failure in acute pancreatitis, so, although we often find ACS in patients with severe acute pancreatitis, we cannot merit this as a prediction score in ACS.

SOFA score is defined by the sum of six organ system scores (respiratory, cardiovascular, renal, coagulation, liver and neurologic), ranging from 0 (normal) to 4 (severe derangement) for each organ system. The SOFA score is calculated using the worst values of the day. By using the SOFA (or another similar) scoring system to define end-organ failure associated with IAH, one accepts the fact that a SOFA score of 3 for one organ system is not equivalent to a SOFA score of 3 of another organ system as far as outcome prediction is concerned. In addition to the calibration bias, the SOFA score does not account for organ systems which are not included in the score, of which the most important is the gastrointestinal system.

Apache II is very commonly used in the ICU, it is applied in the first 24 hours of admission in an intensive care unit; this severity score was designed for adult patients, therefore in has not been validated for use in children or young people aged under ${ }^{16}$.

Depending of the pathology that is responsible for ACS in a patient, we should use prediction and severity scores to conduct a more precise diagnostic, but have into account that low values in this scores doesn't mean that ACS or IAH is absent; always measure IAP. 
The most asked question in the years that followed ACS concept was: how do we recognize it early and what is the best treatment method?

As with most syndromes, there exists a prodromal phase before obvious signs and symptoms become manifest. Firstly we should always monitor IAP in these patients: open or blunt abdominal trauma, mechanically ventilated ICU patients with organ dysfunction, patients with a distended abdomen and signs of ACS (oliguria, hypoxia, hypotension, unexplained acidosis, mesenteric ischemia), patients with abdominal packing after temporary abdominal closure.

When we have a confirmation of IAH and organ dysfunction, we can proceed treating the patient for ACS. Since massive fluid resuscitation is associated with both primary and secondary ACS, several authors have suggested that if the fluid resuscitation could be limited, the patient's morbidity could be reduced ${ }^{21,22}$.

Over the years most studies concerning the temporary abdominal closure methods were made on the efficiency of Bogota bag (large saline infusion bag) and vacuum assisted wound closure. No major differences were found in the outcome of the patients, so most centers prefer Bogota bag because it's cost efficient and young surgeons can quickly master the technique. This plastic bag is sewn to the skin with strong nylon or polypropylene suture material. Drains and self adhe- sive foil can be used to achieve better control of the peritoneal fluid and barrier function. The Bogotá bag is efficient in minimizing the occurrence of ACS in those patients who require vigorous ICU resuscitation ${ }^{23}$.

\section{CONCLUSIONS}

Abdominal compartment syndrome and intra-abdominal hypertension are not two entities that can be ignored by a surgical or non-surgical clinician. The high rates of mortality and morbidity should be an attention signal for the learning curve of managing a critically ill patient.

IAH and ACS are significant causes of organ failure, high resource utilization, decreased economic productivity, and high mortality among a wide variety of patients. An extensive progress has been made in the field of IAH and ACS over the past decade, but there is significant work yet to be done.

Compliance with ethics requirements: The authors declare no conflict of interest regarding this article. The authors declare that all the procedures and experiments of this study respect the ethical standards in the Helsinki Declaration of 1975, as revised in 2008(5), as well as the national law. Informed consent was obtained from all the patients included in the study.

\section{References}

1. An G, West MA. Abdominal compartment syndrome: a concise clinical review. Crit Care Med. 2008 Apr; 36(4):1304-10. doi: 10.1097/CCM.0b013e31816929f4.

2. Schein M, Wittmann D, Aprahamian C, Condon R. The abdominal compartment syndrome: the physiological and clinical consequences of elevated intra-abdominal pressure. J Am Coll Surg. 1995;180:745-753.

3. Saggi B, Sugerman H, Ivatury R, Bloomfield G. Abdominal compartment syndrome. J Trauma. 1998;45:597-609.

4. World Society of the Abdominal Compartment Syndrome. Mission statement. World Society of the Abdominal Compartment Syndrome Web site.http://www.wsacs.org.

5. Malbrain M, Cheatham M, Kirkpatrick A. Results from the International Conference of Experts on Intra-abdominal Hypertension and Abdominal Compartment Syndrome, I: definitions. Intensive Care Med. 2006;32(11):1722-1732.

6. Maxwell RA, Fabian TC, Croce MA et al. Secondary abdominal compartment syndrome: An underappreciated manifestation of severe hemorrhagic shock. J Trauma. 1999 Dec;47(6):995-9.

7. Collee GG, Lomax DM, Ferguson C, Hanson GC. Bedside measurement of intra-abdominal pressure (IAP) via an indwelling naso-gastric tube: clinical validation of the technique. Intensive Care Med. 1993;19:478-480.

8. Albrain M, De Laet IE. Intra-abdominal hypertension: evolving concepts. Clin Chest Med. 2009;30:45-70.

9. Balogh Z, McKinley BA, Holcomb JB et al. Both primary and secondary abdominal compartment syndrome can be predicted early and are harbingers of multiple organ failure. J Trauma. 2003; 54(5):848-859

10. Balogh Z, McKinley BA, Cocanour CS et al. Secondary abdominal compartment syndrome is an elusive early complication of traumatic shock resuscitation. Am J Surg. 2002; 184(6):538543.

11. Cheatham ML. Abdominal compartment syndrome. Curr Opin Crit Care. 2009;15(2):154-162. doi: 10.1097/MCC.0b013e328 3297934

12. Malbrain MLNG, Cheatham ML, Kirkpatrick $A$, Sugrue $M$, Parr M, De Waele J, Balogh Z, et al. Results from the international conference of experts on intra-abdominal hypertension and abdominal compartment syndrome. I. definitions. Intensive Care Med. 2006; 32(11):1722-1732. doi: 10.1007/s00134-0060349-5

13. Kirkpatrick A, Roberts D, De Waele J, Jaeschke R, Malbrain M, De Keulenaer B, Duchesne J, Bjorck M, Leppaniemi A, Ejike J, Sugrue M, Cheatham M, Ball IR, Blaser A, Regli A, Balogh Z, D'Amours S, Debergh D, Kaplan M, Kimball E, Olvera C. In- 
tra-abdominal hypertension and the abdominal compartment syndrome: updated consensus definitions and clinical practice guidelines from the world society of abdominal compartment syndrome. Intensive Care Med. 2013;39:1190-1206. doi: 10.1007/s00134-013-2906-z.

14. Ivatury RR, Sugerman $H J$, Peitzman AB. Abdominal compartment syndrome: recognition and management. Adv Surg. 2001;35:251-269.

15. Sugrue $M$, Bauman A, Jones F, Bishop G, Flabouris A, Parr $M$, Stewart A, Hillman K, Deane SA. Clinical examination is an inaccurate predictor of intraabdominal pressure. World J Surg. 2002;26(12):1428-1431. doi: 10.1007/s00268-0026411-8.

16. Walker J, Criddle LM. Pathophysiology and management of abdominal compartment syndrome. Am J Crit Care. 2003; 12(4): 367-371. quiz 372-363

17. Ball CG, Kirkpatrick AW. Progression towards the minimum': the importance of standardizing the priming volume during the indirect measurement of intra-abdominal pressures. Critical Care (London, England) 2006;10(4):
18. Service WAH. Measurement of Intra-abdominal Pressures. In: Health. NSW, editor. Intensive Care Nepean Hospital. 2004.

19. Sanchez NC, Tenofsky PL, Dort JM et al. What is normal intraabdominal pressure? Am Surg 2001; 67(3):243-248

20. Carâp A, Popa F, Socea B, Moculescu C, Păunică G, I. Păun, BuduVV, Constantin VD. Risk factors for increased intra-abdominal pressure in severe acute pancreatitis. Arch Balk Med Union. 2015; 50(4):498-502.

21. Mayberry JC, Welker KJ, Goldman RK et al. Mechanism of acute ascites formation after trauma resuscitation. Arch Surg. 2003 Jul; 138(7):773-6

22. Balogh Z, McKinley BA, Cocanour CS et al. Supranormal trauma resuscitation causes more cases of abdominal compartment syndrome. Arch Surg. 2003; 138:637-43.

23. Offner PJ, de Souza AL, Moore EE et al. Avoidance of abdominal compartment syndrome in damage-control laparotomy after trauma. Arch Surg. 2001 Jun;136(6):676-81. 
